\title{
Can Online Reflections Assist in the Development of Reflective Thinking?
}

\author{
A Narration of the Experiences of Teachers in Saudi Arabia
}

\author{
Dr Shatha Almalki \\ Imam Abdulrahman Bin Faisal University, Saudi Arabia
}

\begin{abstract}
Across the globe, reflective thinking is considered a critical aspect of learning and professional development in teacher preparation. However, for reasons like time constraints and curriculum complexity, there are many international contexts where reflection is currently an adjunct activity in teacher training programmes. While engaging in reflection may be demanding for trainee teachers who do not have the experience, it may be considerably more difficult within an education system that, as is the case in many countries, lacks support for the development of metacognitive skills. The relevant literature indicates that the use of technology-focused reflective methods can improve the reflective abilities of trainee teachers. Thereby, the implementation of technology can facilitate and motivate pre-service educators to engage in reflection .

This research examines this context and attempts to understand the perceptions and insights of pre-service teachers' experiences when engaging in reflection by using technology to facilitate their reflections to help them improve both professionally and personally during their school placement journey. A combination of action research framework design and narrative practice and analysis was used to study 12 elementary pre-service teachers in Eastern Saudi Arabia. This analysis exposes their stories as they develop their reflective frameworks. The technology adopted in this research used novel forms of graphic representation to help aid understanding and development of complex reflective concepts and their stages within this group of trainee teachers. The research has implications for the development of reflective thinking in training contexts unfamiliar with reflectivity and its significance in teacher growth.
\end{abstract}

\section{KEYWORDS}

reflection, teacher training, technology

\section{ACM Reference Format:}

Dr Shatha Almalki and Professor Caroline Walker-Gleaves. 2021. Can Online Reflections Assist in the Development of Reflective Thinking?: A Narration of the Experiences of Teachers in Saudi Arabia. In 2021 2nd International Conference on Education Development and Studies (ICEDS 2021), March 09-11, 2021, Hilo, HI, USA. ACM, New York, NY, USA, 4 pages. https://doi.org/10. $1145 / 3459043.3459045$

Permission to make digital or hard copies of all or part of this work for personal or classroom use is granted without fee provided that copies are not made or distributed for profit or commercial advantage and that copies bear this notice and the full citation on the first page. Copyrights for components of this work owned by others than the author(s) must be honored. Abstracting with credit is permitted. To copy otherwise, or republish, to post on servers or to redistribute to lists, requires prior specific permission and/or a fee. Request permissions from permissions@acm.org.

ICEDS 2021, March 09-11, 2021, Hilo, HI, USA

(C) 2021 Copyright held by the owner/author(s). Publication rights licensed to ACM. ACM ISBN 978-1-4503-8961-7/21/03 ..\$15.00

https://doi.org/10.1145/3459043.3459045

\author{
Professor Caroline Walker-Gleaves \\ Newcastle University, UK
}

\section{INTRODUCTION: THE IMPORTANCE OF TECHNOLOGY-ENHANCED REFLECTION AND ITS PLACE IN TEACHER DEVELOPMENT}

Teaching is complex and fluid by its very nature $[1,2]$ and teachers must be both flexible and innovative (Jarvis, 2002) to keep developing and honing their skills [3-5] and acquiring new ones to teach effectively [6]. But being an effective teacher is arguably far more than acquiring skills, techniques or strategies; '[effective teaching] is a deliberate philosophical and ethical code of conduct' [7, p249]. Harris emphasises that 'effective teaching is linked to reflection, enquiry and continuous professional development and growth' [8, p179]. In other words, to become a teacher who is concerned with perpetual self-development and who is fully cognizant of the ethical and moral implications and impacts that teaching is concerned with, educators must engage in ongoing reflective thinking, which comprises, according to Dewey, understanding one's experiences, evaluating one's thoughts, uncovering how these two elements contribute to ongoing behaviour, and finally, understanding how one can continually change for the better [5].

Technology plays a significant facilitating role in reflective thinking, enabling synchronous communication and continual dialogue with spatial and temporal limitations, which can scaffold ongoing support and comment from tutors and peers [9]. According to Almalki ,it "literally allows training teachers to "practice" the knowledge and skills that they have learned to practice being a teacher, so that they develop authentically' [9]. Critically, though, technology also promotes among trainee teachers the notion of autonomy and encourages and expects student teachers to play an active role in their own learning. Arguably, without technology providing a forum for constant dialogue and questioning, teacher learning would take longer and be more solitary and less open to change - all qualities and issues that are important and accepted parts of a teachers' practices in the field $[3,10]$.

However, while reflective thinking is an international concern within teacher training, it is not universally actualised in teacher training institutions, in many contrasting teacher training philosophies or in a diverse range of countries [9], and emphases on reflective thinking are variable. Saudi Arabia, the setting for this research, employs a supervision model in teacher preparation programmes that remains traditional and does not encourage student teachers to think or reflect on their practices [11-13]. This study is an important and novel contribution to the literature because it adopts technology to facilitate and motivate pre-service teachers to engage in reflection and explores pre-service teachers' experiences and perspectives when they engage in reflection via the use of such technology during their school placement journeys. 


\section{THE DIFFICULTY OF REFLECTIVE THINKING AND THE AMELIORATIVE EFFECTS OF TECHNOLOGY}

\subsection{The critical importance of reflective thinking in teacher professional learning}

The literature consistently demonstrates that, for trainees and established teachers, reflective thinking is not easy [14-16]. Moreover, the processes required for deep and persistent reflection, especially when it is linked to the grades and assessments of training teachers' abilities and expertise, are difficult and sometimes unpleasant [9] Furthermore, reflection itself can give rise to negative thoughts and self-questioning that stand as impediments to professional development and act as unhelpful foci for reflection [9]. Many of these difficulties can be ameliorated with appropriately scaffolded reflective stages and processes and contributions from tutors, who can maintain a secure and professionally reassuring ethos, especially when reflection is an unfamiliar and uncomfortable process $[15,17,18]$.

\subsection{The innovation and scaffolding of technology-enhanced reflection}

The inception of technology has fostered and facilitated significant developments for teachers' developments in reflective thinking $[19,20]$, most notably in that it can provide them with multiple opportunities to critique and question their practices in contexts that are independent of time and place [21-23]. Through technology, trainee teachers may deepen their reflections, clarify their purposes and practices of reflection and, most importantly, grow professionally during their field experience [24, 25].There are other important reasons that technology can claim to be an important innovation within the sphere of reflective learning, related to the fact that pre-service teachers can learn before being placed in a real school by implementing case-based, micro-teaching episodes online [12], which can help them practise teaching in a safe environment and put their theoretical knowledge into practice.

\subsection{The difficulties and diversity of models of teacher reflective thinking}

In all teacher training contexts, as examined internationally, field experience is considered a critically important part of teacher education programmes [26], providing pre-service teachers with a chance to put their knowledge and theory into practice in a real classroom environment. Additionally, it enables them to generate new knowledge based on their theoretical knowledge and experience [27, 28]. Within this field practicum, reflective thinking is a key part of training teachers' skills and knowledge developments, giving trainees a framework that enables them to make sense of complex decision making while also offering them pathways to improve their practices, based on a variety of reflective stages, from articulation to description, through to analysis, onto reconstruction and synthesis. But countries vary in their orientations to including and developing reflective thinking within their teacher training curricula. In the Saudi context, for example, there is a need to establish a partnership between universities and schools [11, 12].However, there are economic limitations to doing so, related to structural matters, policy decisions and financial targets [9]. As such, a practical solution that is supported in the teacher development literature is the technological option researched in this paper - the adoption of technologically enhanced teacher reflection through means of online journals.

\section{RESEARCH DESIGN AND METHODS}

This study explores Saudi Arabian pre-service teachers' experiences and perspectives when using technology to promote the reflection process during training. A combined action research framework design with narrative analysis was adopted, with a sample of 12 elementary pre-service teachers within a teacher training college in Eastern Saudi Arabia. The research considered three questions:

- 1. To what extent do Saudi pre-service teachers reflect on their practices and what are their attitudes and orientations towards using reflective journals as a method of learning?

- 2. What are some impedimentary and disincentivising factors that Saudi pre-service teachers believe limit the use of electronic reflective journals as a method of learning within their field experiences?

- 3. What do Saudi pre-service teachers believe to be the affordances and facilitatory factors for using electronic reflective journals as a method of learning within their field experiences?

Our research had to account for both teachers' lack of full appreciation of the possibilities of reflective thinking and their partial understanding of what it might look like as a principle of training. To do this, the researchers had to achieve two things concurrently: to act as both support agents to assist in fostering and initiating trainees into reflection and reflective knowledge; and as change agents to educate and cyclically interrogate and question, and to scaffold trainees in reflective acting and behaviour. As such, we needed to listen to the teachers' stories and encourage them to narrate their orientations and experiences and shape the overall purpose and practice of the research. We achieved the former through narrative practice and analysis, and the latter through action research design. In practice, this meant that we carried out specific activities to achieve our research aims. Over three months, we conducted workshops introducing reflective thinking, and explaining and embedding reflective thinking frameworks; we introduced and reiterated models of reflective writing, linking thinking to writing to acting; we taught and then developed an interactive blog featuring the translation of reflective thinking practice to subject bases in the classroom; we modelled reflective blogging and used a newly designed graphic representation of reflective concepts that would motivate trainees. During this process of actively teaching, modelling and scaffolding reflection, we also interviewed the trainee teachers individually three times, regularly read their blogs and conducted focus group meetings in which trainees discussed their experiences with reflective thinking and the facilitators of and impediments to technological innovations. The data was paradigmatic narrative analysis, through which we aimed to recognise common themes among the stories of trainee teachers [9]. Common themes were derived from the main research foci, as represented in the research questions; however, sub-themes and the coding process emerged inductively from the research data. 


\section{FINDINGS AND ANALYSIS}

\subsection{Saudi pre-service teachers' attitudes and orientations towards using reflective journals as a method of learning}

The research demonstrated that Saudi pre-service teachers only partially and sporadically reflected on their practices, and that this made their actual teaching difficult and stressful:

"When I started teaching, I felt that was not how I imagined myself practicing teaching. I was talking more than the students. I did not give them a chance to respond, or to interact with me or with each other." (Nada)

But that reflection, even in its early stages, was causing them to rethink their attitudes and behaviour:

"It helped me to change internally and externally in my professional life and affected me positively in my personal and social life. Building my self-confidence and recognising my mistakes and weaknesses are essential in my case to develop as a teacher." (Rana)

Critically, the processes of reflective thinking caused some painful revelations in terms of exposing their hitherto random implementation solutions in classroom behaviour management:

"I was thinking of trying to punish some of my students by making them stand up when they make a mistake... because my brother is the same age as my students, and his level of achievement is good. I asked him how his teacher treats them. Before I knew about the reflection concept, I was not sitting down to think about the reasons behind my problems; I was directly looking for the solution. The nearest [and] the easiest solution... which often was by applying the suggested solutions from others straightaway." (Hanan)

\subsection{Factors limiting the use of electronic reflective journals among Saudi pre-service teachers}

This research highlighted the great initial apprehension toward having each other's writing about teaching speculated upon, thus keeping comments only positive and affirmative:

"My friends shared their journals in the online group for all students in the last semester of their study... but they did not receive any critical comments... They just tell them that your journals are beautiful; we liked them, and we liked your solutions." (Marwa)

And this revealed deep-seated unease about the purpose of the reflection:

"It is hard for us to criticise each other in front of the others... there is no need to write it to be seen by others... we can ask our friends and they will tell us their immediate answers anyway." (Asma)

As a result, several trainees justified their initial reservations by arguing that the tutors and other trainees were simply too busy to be disturbed:
"Even in the WhatsApp group we do not like to bother you with our discussion; indeed, we have our own WhatsApp group, and we tend to discuss our issues there. We don't need more discussion; we just need to get on with our work." (Kholoud)

\subsection{Facilitatory and affordance factors in the use of electronic reflective journals among Saudi pre-service teachers}

Our research exposed the extent to which trainee teachers engaged in active learning about their teaching. Previously, they believed that they must either ask their tutors, or they must remain silent about the difficulties they were having. The technology presented a third way: they could ask each other, or they could learn vicariously from others' blogs:

\begin{abstract}
"My view changed. I used to deal with things at a very superficial level or not at all. I never considered and focused carefully on my incidents or tried to address them intellectually. Now, with reflection... thank God... my view of the incidents has changed." (Haifa)
\end{abstract}

Most trainees used their blogs in two different and contrasting ways - as a whole group learning vehicle, where they saw the blog content as a dynamic encyclopaedia, and as an individual learning log that both measured and reassured them of their own developmental progress:

"I like to read my online journals over and over because it helps me to recognise how much I have learned... For example, with regard to managing the classroom, I realised that I was exaggerating the situation and that things have now become much better." (Kholoud)

Some trainees felt that the blogs and reflection presented them with many solutions. That, in itself, was another form of reflection in which they could evaluate the most useful response to their particular situations:

"From the online reflections, I learned many skills. How to write any issues clearly... how to search for more than one solution and how to choose the effective solution, not the easy one... before that I was just complaining." (Aldana)

\section{DISCUSSION AND CONCLUSIONS}

Our research shows that reflective thinking processes can be significantly improved through ongoing dialogue with tutors and peers, and through opportunities to question particular critical incidents and discuss their place in reflection levels and stages of development [9]. This study shows that one way of achieving this is through the adoption of writing journals [9]. However, comments from trainee teachers show that utilising written journals alone - without providing trainee teachers with the means to both question the bases of their reflections, as well as describe and analyse how their behaviour is changing - often leads to a superficial, descriptive level of reflection [16, 29]. Using a variety of action-research led approaches to reflective dialogue [9], trainee teachers in this 
study compared reactions to critical incidents, discussed their varied viewpoints, observed each other's feelings and thoughts and, perhaps most importantly, did this in a safe and ethically bounded environment where they saved face and did not feel threatened by judgment from tutors in summative teaching episodes [9].

While many studies have been conducted in Western democracies and economically advanced and developed countries like the USA, Australia and the UK, which started to implement reflection in teaching two decades ago [10,30-33], the Saudi teacher training system has not kept pace, and the our study showed that there are great impediments to reflective thinking, both in knowledge terms and in practices. Trainee teachers in this study tended to cope to varying degrees with the difficulties and complexities of decision making, and these poorly equipped teachers not only had major difficulties in most situations, but also justified their actions with various personal and structural explanations. Likewise, these teachers often could only make simple modifications to a variety of classroom circumstances and missed opportunities to be creative and adaptable during their learning, remaining passive and waiting for their tutors' guidance to improve.

The literature shows that, while trainee teachers in many different international contexts use reflective thinking to develop professionally, instances in which it is not routinely used - particularly in cases where training tends to be more prescriptive and focused upon technical aspects rather than self-development and critical thinking - are under-researched. Our study contributes original knowledge to fill conceptual and practical gaps and offers important insights. Precisely because the affordances of reflective thinking are not fully realised, teachers were losing opportunities to critically improve their practice, which would only be compounded once they completed their training, thus failing to realise the possibilities of reflective thinking as a way to continually improve. This research, then, might explain why Saudi teachers seem reluctant to take responsibility for their teaching and learning to grow professionally. In conclusion, this demonstrates the singular importance of reflective thinking both for the entire teaching workforce and, critically, for the country's schools and its pupils.

\section{REFERENCES}

[1] Renate Schulz. 2005. The practicum: more than practice. Can. J. Educ. 28, 1-2 147-167 https://doi.org/10.2307/1602158

[2] Linda Finlay. 2008. Reflecting on reflective practice. PBPL Pract. Prof. Learn. Cent 52 (January 2008). 1-27.

[3] Fred Korthagen. 2001. Linking practice and theory: the pedagogy of realistic teacher education. Lawrence Erlbaum Associates Publishers. Mahwah, USA

[4] Rita Hagevik, M. Aydeniz, and C. G. Rowell. 2012. Using action research in middle level teacher education to evaluate and deepen reflective practice. Teach. Teach. Educ. 28, 5 (February 2012), 675-684. https://doi.org/10.1016/j.tate.2012.02.006

[5] Rodgers, Carol and Laboskey, Vicki Kubler. 2016. Chapter 17 Reflective practice. International Handbook of Teacher Education. Springer, 71-104.

[6] Marcia Devlin and Gayani Samarawickrema. 2010. The criteria of effective teaching in a changing higher education context, High. Educ. Res. Dev. 29, 2 (March 2010), 111-124. https://doi.org/10.1080/07294360903244398

[7] Barbara Larrivee. 2000. Transforming teaching practice: becoming the critically reflective teacher, Reflective Pract. 1, 3 (Augest 2000), 293-307. https://doi.org/10. $1080 / 713693162$

[8] Alma Harris. 1998. Effective teaching: a review of the literature, Sch. Leadersh Manag. 18, 2 (Augest 1998), 169-183. https://doi.org/10.1080/13632439869628.

[9] Shatha Almalki. 2020. Exploring the Use of Online Reflective Journals as a Way of Enhancing Reflection Whilst Learning in the Field: The Experience of Teachers in Saudi Arabia. PhD Thesis. ECLS Department Newcastle University.

[10] Marilyn Cochran-Smith and Susan Lytle. 1999. Chapter 8: Relationships of knowledge and practice: teacher learning in communities. Review of Research in Education $24,1.249-305$.

[11] Abdulaziz Kabli. 1999. Initial Training of Male Elementary School Teachers in the Kingdom of Saudi Arabia: An Empirical Study of Contributions by Principals and Teachers to Teaching Practice. Unpublished PhD Thesis. University of Hull.

[12] Layla Al-Zarah. 2008. An Investigative Study of the Female Initial Teacher Preparation Programme in Saudi Arabia in sn Islamic Context. Unpublished PhD Thesis. Durham University.

[13] Nadia Al-jadidi. 2012. The Professional Preparation: Knowledge and Beliefs of Kindergarten Teachers in Saudi Arabia. Unpublished PhD Thesis. University of Exeter.

[14] Dewey, John. 1933. How We Think: A Restatement of the Relation of Reflective Thinking to the Educative Process. D.C.Heath and Company. London, UK.

[15] Dawn Francis. 1995. The reflective journal: a window to preservice teachers' practical knowledge. Teach. Teach. Educ. 11, 3 (May 1995), 229-241. https://doi. org/10.1016/0742-051X(94)00031-Z

[16] Russell Rogers. 2001. Reflection in higher education: a concept analysis. Innov. High. Educ. 26, 1 (September 2001), 37-57.

[17] Valerie Hobbs. 2007. Faking it or hating it: can reflective practice be forced? Reflective Pract. 8, 3 (July 2007), 405-417. https://doi.org/10.1080/14623940701425063

[18] Jukka Husu, A. Toom, and S. Patrikainen. 2008. Guided reflection as a means to demonstrate and develop student teachers' reflective competencies. Reflective Pract. 9, 1 (February 2008), 37-51. https://doi.org/10.1080/14623940701816642

[19] James Makinster, S. Barab, W. Harwood, and H. Andersen. 2006. The effect of social context on the reflective practice of preservice science teachers: incorporating a web-supported community of teachers. J. Technol. Teach. Educ. 14, 3 (January 2006), 543-579.

[20] Heng Hou. 2015. What makes an online community of practice work? A situated study of Chinese student teachers' perceptions of online professional learning. Teach. Teach. Educ. 46 (November 2015), 6-16. https://doi.org/10.1016/j.tate.2014. 10.005

[21] Hilda Borko, J. Whitcomb, and D. Liston. 2009. Wicked problems and other thoughts on issues of technology and teacher learning. J. Teach. Educ. 60, 1 (February 2009), 3-7. doi: 10.1177/0022487108328488.

[22] TeresaScruggs Thomas. 2009. Online vs Face-to-Face: Educator Opinions on Professional Development Delivery Methods. Unpublished PhD Thesis. The University of Alabama.

[23] Bart Rienties, N. Brouwer, and S. Lygo-Baker. 2013. The effects of online professional development on higher education teachers' beliefs and intentions towards learning facilitation and technology. Teach. Teach. Educ. 29, 1 (September 2013), 122-131. https://doi.org/10.1016/j.tate.2012.09.002

[24] Guolin Lai and Brendan Calandra. 2010. Examining the effects of computer-based scaffolds on novice teachers' reflective journal writing. Educ. Technol. Res. Dev. 58, 4 (February 2010), 421-437. DOI 10.1007/s11423-009-9112-2

[25] Külli Kori, Margus Pedaste, Äli Leijen and Mario Mäeots. 2014. Supporting reflection in technology-enhanced learning. Educ. Res. Rev. 11 (January 2014), 45-55. https://doi.org/10.1016/j.edurev.2013.11.003

[26] Omayya ,Al-hassan, Ali Al-barakat and Yazid Al-hassan. 2012. Pre-service teachers' reflections during field experience. J. Education Teach. 38, 4 (December 2012), 419-434. https://doi.org/10.1080/02607476.2012.707918

[27] Melanie Shoffner. 2018. Informal reflection in pre-service teacher education. Reflective Pract. 9, 2 (May 2008), 123-134. http://dx.doi.org/10.1080/ 14623940802005392

[28] Minna Korkko, Outi Kyro-Ammala, and Tuija Turunen. 2016. Professional development through reflection in teacher education. Teach. Teach. Educ. 55 (December 2016), 198-206. http://dx.doi.org/10.1016/j.tate.2016.01.014

[29] Rida Hourani. 2013. Pre-service teachers' reflection: perception, preparedness and challenges. Reflective Pract. 14, 1 (October 2013), 12-30. http://doi.org/10. 1080/14623943.2012.732947

[30] John Bain, Roy Ballantyne, Jan Packer and Colleen Mills. 1999. Using journal writing to enhance student teachers' reflectivity during field experience placements. Teach. Teach. Theory Pract. 5, 1 (July 1999), 51-73. DOI: 10.1080/1354060990050104

[31] Reilley Anne Freese. 1999. The role of reflection on preservice teachers' development in the context of a professional development school. Teach. Teach. Educ. 15, 8 (February 1999), 895-909. https://doi.org/10.1016/S0742-051X(99)00029-3

[32] Karen Deshon Hamlin. 2004. Beginning the journey: supporting reflection in early field experiences. Reflective Pract. 5, 2 (October 2004), 167-179. https: //doi.org/10.1080/14623940410001690956

[33] Charlotte Meierdirk. 2016. Is reflective practice an essential component of becoming a professional teacher? Reflective Pract. 17, 3 (May 2016), 369-378. doi: 10.1080/14623943.2016.1169169. 